\title{
A DEMOGRAPHIC ANALYSIS OF CONSUMERS' PREFERENCE FOR GREEN PRODUCTS
}

\author{
Abdul Bashiru JIBRIL (D), Michael Adu KWARTENG@, Miloslava CHOVANCOVA(D \\ Department of Management and Marketing, Faculty of Management and Economics, \\ Tomas Bata University, Mostni 5139, 76001, Zlin, Czech Republic \\ *E-mails:jibril@utb.cz,mallambash13@gmail.com
}

\begin{abstract}
Purpose - the aim of this research is to understand and present the outcomes of the strength of association between consumers and the use of the green (herbal) product from a demographic viewpoint. By extension, it measures the magnitude of dependents among demographic factors influencing the use of the green product in a developing country.
\end{abstract}

Research methodology - to evaluate consumer's demographics on the use of the green (herbal) product, 207 participants took part in the survey through a structured questionnaire. Data were obtained from users of green products (specifically herbs) in Ghana. A nonparametric test precisely chi-square test $\left(\mathrm{x}^{2}\right)$ and Spearman's correlation $r_{\mathrm{s}}$ were employed for our empirical analysis.

Findings - the paper indicated the youthful population as the highest number of users of the green product in the herbal market. Results from the nonparametric test (Spearman's rho) revealed that demographic factors (gender, age, education, and occupation) have an inverse relationship on the use of the green product. Whiles the chi-square test also discloses insignificant relationships among the observed attributes. This suggests that there is no empirical evidence to support the claim that use of green product depends on demographic factors of consumers.

Research limitations - the limitation of this study considered the research scope, taking into account a smaller sample size for the study hence, future researchers should expand the sample size as well the other demographic variables necessary for a similar study.

Practical implications - the practical implication of this study gives insights to practitioners and marketers in the herbal industry on how best they can progress in their quest to sustain in the business.

Originality/Value - the present study aided in widening the scope of consumer behaviour towards the green product in the marketing discipline taken into consideration the widespread competition in the business nowadays especially in the herbal (green product) market.

Keywords: consumers' preference, demographic factors, green product, nonparametric test, developing country.

JEL Classification: M2, M21, M31.

Conference topic: Contemporary Organizations Development Management.

\section{Introduction}

Green products, especially herbal products are recognized as natural sources of remedy in healthcare for decades, hence it is considered an indigenous system of medicine (Pal \& Shukla, 2003). While extant literature has shown that some herbal medicines may have severe consequences, it is now in great demand in the developing world mainly for primary healthcare. Natives of these countries use it not because they are inexpensive but also for better cultural acceptability, better compatibility with the human body and minimal side effects. Similarly, most green products on the market today have received substantial attention by scholars and practitioners regarding the demand and usefulness of these products (Pal \& Shukla, 2003; Pan et al., 2014). The availability of plant products has been utilized with varying success to cure and prevent diseases throughout history (Raskin et al., 2002). Also, medicinal plants report date back at least 5000 years ago suggested earlier use of medicinal plants in India. Due to the side effects of some synthetic products, herbal products are gaining popularity in the world market (Elvin-Lewis, 2001; Patwardhan, Vaidya, \& Chorghade, 2004). Henceforth, it has been noted that one major reason for the popularity and acceptability is the belief that all natural products are safe. 
For the past decade, there has been a gradual shift in universal trend from synthetic to herbal medicine usage, which could be described as 'Return to Nature'. Medicinal plants have been known for millennia and are highly esteemed all over the world as a rich source of natural cure for the prevention of diseases and ailments (Samiee, Shimp, \& Sharma, 2005; Sharma, Shanker, Tyagi, Singh, \& Rao, 2008). Though nature has bestowed in many countries with an enormous wealth of green plants for an example India has often been referred to as the Medicinal Garden of the world. In fact, countries with ancient civilizations such as China, India, South America, Egypt, just to mention a few are still using several plant remedies for various conditions. In this regard, India has a unique position in the world where a number of recognized indigenous systems of medicine generally known as local brands (such as Ayurveda, Siddha, Unani, Homeopathy, Yoga, and Naturopathy) are being utilized for their healthcare. It is also undeniable that herbal drugs are popular among the rural and urban community of India (Samiee et al., 2005; Sharma et al., 2008). Again, the demand for plant-based medicines (green products), food supplement, cosmetics, among others are increasing in both developing and developed countries, due to the growing recognition and economic benefits. According to Sharma et al. (2008); Semenya, Potgieter, Tshisikhawe, Shava, and Maroyi (2012) there is a revival of interest with herbal-based medicine due to the increasing realization of the health hazards associated with the indiscriminate use of modern medicine.

In the years before and after the patronization of herbal medicine, a sizable number of research works and publications have been authored; ranging from various topics and issues in line with the use of the herbal (green products) medicines as earlier stipulated. Yet, none so far has attempted to delve into the strength of association between consumers and the use of the green (herbal) product, taking into account the developing country. The scant but few available literature reviews were conducted differently by only concentrating on the human use of the green product as well as some specific area in the African sub-region. For instance, Makunga, Philander, and Smith (2008) reported on different reviews of literature on herbal and green product usage in South Africa whiles Kairu et al. (2013) conducted a reflective analysis of how herbal or medicinal products that cure heart-related diseases are disappearing from the forest zone in recent times.

Furthermore, the methodological approaches used in review articles conducted on green or herbal medicinal products utilization are dissimilar from what this paper proposes. This study is unarguably seen and positioned to add to existing theories and fill research gaps in the following ways. First, this study appears to add to the scanty works undertaken to explore the trend of consumer purchasing decision regarding demographic factors influencing the patronage and usefulness of green products. This is in line with the paucity of available researches geared towards consumer preference of local green products within the developing economy. Secondly, this paper seeks to examine the consumers' inclination towards the locally green (herbal) product from a demographic viewpoint. Although, it would be appropriate to recognize that, the herbal industry has a market potential in terms of job creation and revenue generation for the country as a whole (Agbonifoh \& Elimimian, 1999). The paper sought to offer empirical answers to marketers and practitioners especially within the spheres of the herbal industry for deeper understanding and support. This will unearth the unexplored avenue situated in the herbal market. The theoretical benefit of this study would be to widen the scope of consumer behaviour and brand management in the marketing discipline. Subsequent phases of this paper are as follows; literature review, methodology, results and discussion, conclusion and recommendation for future studies.

\section{Literature review}

\subsection{Global Trend of Green (Herbal) Market}

Globalization has led to the creation of enabling opportunity for the marketing and advertising of numerous products from both developing and underdeveloped economies. For example, China's food and textile industry, as well as medicinal herbal products businesses, have characterized heavily in the international market (Rath, 2005; Van Andel, Myren, \& Van Onselen, 2012). Considering the growing importance of the herbal industry, countries that are dominant or engaged in such activities has experienced among the following; increase in export and import of raw drugs (green product), rise in the domestic and foreign business in traditional medicines produced from raw green plant, a significant rise in the research on the biochemical and clinical performances, consumer's purchasing pattern on medicinal plant (green plant), significant increase in patent of herbal product, just to mention a few (Kumar \& Janagam, 2011). However, during the past decade, there has been a report indicating an increase in western people's interest in herbal medicine (green product) especially the western scientists. Most of their research into medicinal plants was tailored towards developing and underdeveloped countries so as to strategize and develop more effective and safe herbal products for its concern to both consumers and marketers (source: World Congress on Medicinal and Aromatic Plants for Human Welfare (WOCMAP III ${ }^{1}$ ), 2003, held at Chiangmai, Thailand).

Additionally, worldwide consumption pattern of green product (herbal product) has seen a remarkable change during the middle of the last century. However, by extension, it is interpreted to mean demand and use of green products have increased dramatically over time now with a projected increase in the coming years. Statistically, it has been reported that the global herbal medicine market size was valued at USD 71.19 billion in 2016 and is projected to show a profitable or appreciable growth over the forecast period (Aneesh, Hisham, Sekhar, Madhu, \& Deepa, 2009). The 
increase is attributed to the increasing preference of consumers towards traditional medicines (Ayurveda, Unani and Traditional Chinese Medicine), these products are well-known in the Indian herbal industry and also in the world market with a minimal side effect (Pandey, Singh, \& Dalla, 2017; Rath, 2005). To add, it has been estimated in Figure 1 that an increase in substantial research investments and funding will support the growth of the herbal market in the coming years.

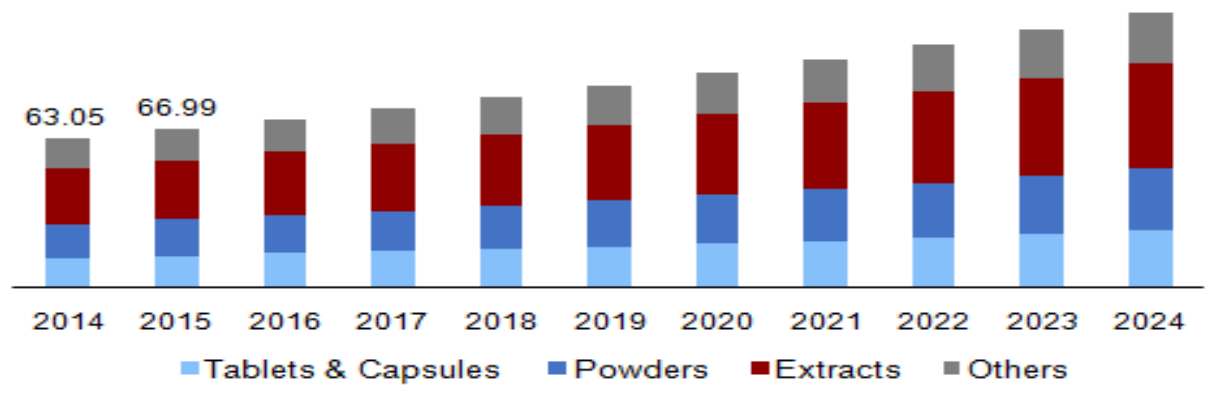

Figure 1. Global herbal medicine market revenue, by product, 2014-2024 (USD Billion)

(source: HEXA RESEARCH, Herbal Medicine..., 2017)

From the above, it is known that global plant-derived products market is expected to gain momentum over the projected period due to the low cost of herbal medicines compared to modern medicine. These drugs are witnessing significant progress at the global level. For example, in China, the intervention of these drugs has helped to remedy acute respiratory syndrome (SARS) (Lu Wang \& Xiong Chen, 2004). The less expensive nature of these herbal product has increased the preference for cost-effective treatment alternative for various medical conditions such as cold \& cough, kidney disorders, digestive problems, and chest congestion is anticipated to enhance the further acceptance of these medicine forms worldwide (Balabanis, Diamantopoulos, Mueller, \& Melewar, 2001; Watson \& Wright, 2000).

Meanwhile, the herbal product industry is undeniably a lucrative business in the world market today. Countries such as China, India, Singapore, and Malaysia have some part of the revenue generated for their economies coming from this industry. Thus, these countries do make great investments in their herbal research industries with the view of boosting their economies (Brown, 1999; Kotler \& Gertner, 2002).

\subsection{Local Ghanaian Herbal Market in Context}

In fact, Herbal treatment constitutes an important aspect of most health delivery systems in Africa for that matter in some parts of the world today (WHO report). For example, China, India, and Singapore have made a greater impact on the Asian and African markets with most of their herbal products. Apart from giving identity to the nation through its brand and potency, the herbal product identifies an individual company as to its area of specialization in terms of health delivery (Thongruang, 2008). The fact that consumers in Ghana have traditionally used herbal/traditional remedies to treat common ailments has given rise to the demand for branded herbal/traditional products. The medicinal plants traded at the market were mostly used for various purposes including; women's health, in rituals, as aphrodisiacs, and against sexually transmitted diseases. As a matter of fact, herbal medicine (green product) has been used alongside modern medicine in Ghana and many continue to rely on it for their healthcare despite the increasing use of modern medicine. The product has played a significant role in healthcare delivery since time memorial. Studies have shown that approximately $80 \%$ of the world's population, $80 \%$ of the people in developing countries, $80 \%$ of Africans and about $70 \%$ to $75 \%$ of the population of Ghana rely on herbal medicine for their primary healthcare (Adjei, 2013; Jibril, 2017; Van Andel et al., 2012). However, there are no studies regarding the association of consumers' demographics and the use of the product (herbal product) in Ghana, hence this present study focus on that objective.

\subsection{Conceptual Framework and hypotheses development}

The conceptual framework depicts the demographic characteristics of customers of green product (herbal product). It shows how the independent variables (gender, consumer's age, consumer's educational level, and consumer's occupation) affect the dependent variable (green product) and could be shown in Figure 2. To achieve this goal, we developed hypotheses to establish the relationships and dependence of herbal product (green product) and the behaviour of customers; the following hypotheses were set;

H1: The use of the herbal product (green product) depends on gender

$\mathrm{H} 2$ : The use of the herbal product (green product) depends on the consumer's age

H3: The use of the herbal product (green product) depends on consumer's educational level

H4: The use of the herbal product (green product) depends on consumer's occupation 


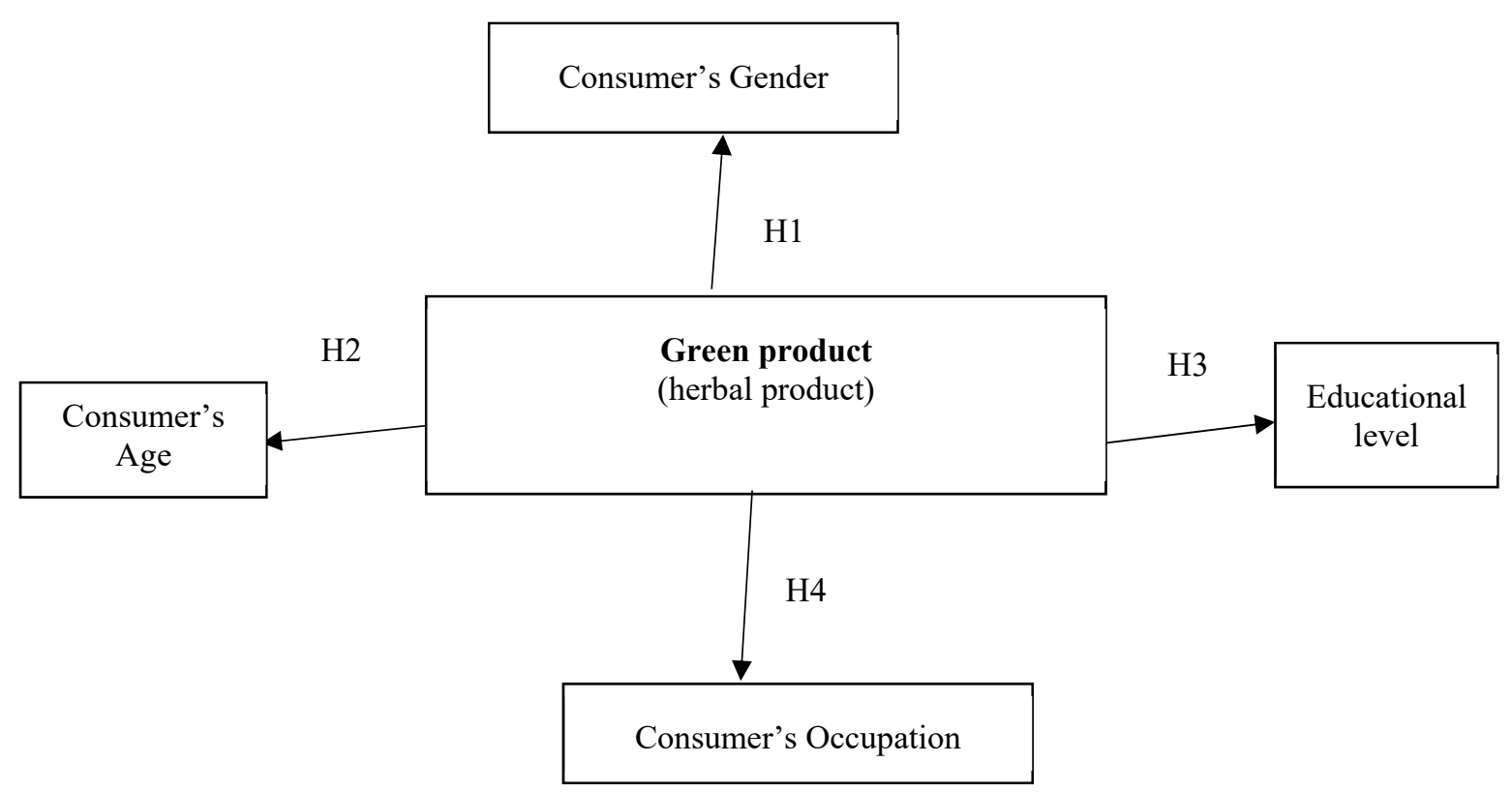

Figure 2. A conceptual framework

\section{Methodology}

\subsection{Surveyed data}

The aim of this research is to understand and present the outcomes on the strength of association between the use of the green (herbal) product from a demographic viewpoint. The 'herbal product' is chosen as our focus since it falls under the category of green product varieties in the green market. Green products based on the simplified definition by many authors include all natural products/services which satisfy the needs of a consumer and have less impact on the environment (Bempong, 2017; D'Souza, Taghian, Lamb, \& Peretiatko, 2007; Roberts, 1996). It is therefore important for readers to note that the green product in this context is described as a herbal product. For the purpose of attaining this goal, we design a research hypothesis for easier interpretation of statistical data for the aforementioned variables. The paper adopted a mixed research approach to gain a deeper understanding of consumer demographic factors (Roberts, 1996). With regards to the scope of primary data, and more essentially, the magnitude of consumer's perception and attitude towards purchases of green product in demographic perspective, 207 valid responses were from consumers or users of the herbal product in the present study (Warner, 1965). More clearly, the questionnaire was geared toward the demographical aspects of respondents; age, gender, marital status, education and occupational level (Olken \& Rotem, 1986).

For the purpose of achieving the stated hypotheses, a simple random sampling technique is employed in order to give an equal chance to the population under study (Madow, 1968). Criteria include among others; geographical proximity, population size, accessibility and affordability in terms of cost were considered in selecting this technique. In response to this sampling method, buyers in the herbal market were recommended for our study since the enumerated criteria befit this purpose. However, with respect to data analysis technique, non-parametric test precisely spearman's correlation $r_{s}$ and chi-square test $\left(\mathrm{x}^{2}\right)$ were employed for the analysis. By virtue of this knowledge, data was implemented in three different phases: firstly, the demographic profiling of consumers, chi-square test of the demographic variables, and lastly the test of Spearman's $r$ correlation among the demographic variables.

\subsection{Measures of demographic characterization}

The pioneers in studying the demographic factors related to this theme were executed by Anderson Jr and Cunningham (1972); Berkowitz and Lutterman (1968). Their studies espouse how individual characteristics predict or influence the buying intention towards the green product. In the same analysis, it was indicated a typical green consumer in terms of gender as a female with the average age of 40 years, complement with a high level of education and socio-economic status(occupation) above average. Similarly, other research in the same domain shown that women were seen as more conscious in the green market than men but men were willing to pay more irrespective of the product brand (D'Souza et al., 2007). However, all these previous works could not highlight the specific product on focus within the green market. Also, the work of this nature has not been done in the context of Africa like Ghana. In view of this, the present study focus on the following demographic variables in the analysis: gender, age, education, and occupation. 
Age:

This variable has been investigated extensively by many scholars and some of them debated that young people (especially youth) are most likely to be delicate to green market issues. Notwithstanding, several studies over the last two decades identified the green consumer has been older than the average(Straughan \& Roberts, 1999). As a matter of fact, the relation that exists between age and other variable were also explored by other authors with varied interpretation (results contradictory). Some authors found non-significant relations between age and use of the green product (Straughan \& Roberts, 1999) while others observe a significant and positive relation (Akehurst, Afonso, \& Martins Gonçalves, 2012).

$>$ Sex:

Also, several authors have examined the influence of gender on green consumer behaviour. In spite of the fact that many women are more conscious and friendly in the green environment, there has not been extensive elaboration from authors who studied the variable, hence results in the literature is not conclusive (Han, Hsu, Lee, \& Sheu, 2011; Straughan \& Roberts, 1999; Valtonen, Markuksela, \& Moisander, 2010)

\section{Education:}

Most studies that include the educational level of consumers have indicated a positive relationship with green consumer attitude (Laroche, Bergeron, \& Barbaro-Forleo, 2001; D'Souza et al., 2007; Han et al., 2011). In view of this, it suggests consumers with a high level of education are more sensitive and conscious in the green market and tend to act accordingly. However, in the works of (Pal \& Shukla, 2003; Straughan \& Roberts, 1999) observed that education does not have a positive relationship with green consumer behaviour and intention.

$>$ Occupation:

According to Awad (2011); Kim (2011); and Roberts (1996), consumers socio-economic status (occupation) usually perceived to have a positive relation to green consumer behaviour and intention. This is based on the general assumption that improved (high standard) of green product calls for a higher price in the green market and vice-versa (Anderson Jr \& Cunningham, 1972). In this regard, authors from the various survey have taken a keen note of this variable in their empirical analysis, but however results are not always convincing (Akehurst et al., 2012)

\section{Results and discussion}

\subsection{Statistical analysis of demographic variables}

The empirical data from the field shows a varied interpretation regarding the demographic outlook of the consumers. In view of this, the frequency of demographic characteristics indicated in Table 1 suggest that most $(50.5 \%)$ males are the dominant users of green (herb) product in the Ghanaian herbal market. Also, most (37.7\%) of consumers between the ages of 21 to 30 liked the use of green product relative to other age categories in this survey. Again research showed that most $(36.2 \%)$ of the sampled respondents are within the bracket of junior and high school certificate while a moderate $(26.6 \%)$ do not have any formal education. The study further inquired the occupational level of the users of the green product and it was indicated that most (32.9\%) are engaged in the informal sector and nearly 19 percent belongs to another category of income earning activities. However, a substantial number of students $(23.7 \%)$ also confirmed to use of the green product a purpose.

Table 1. Demographic profile of respondents (sources: Authors' survey)

\begin{tabular}{|c|c|c|}
\hline Demography & Frequency & Percentage $(\%)$ \\
\hline $\begin{array}{ll}\text { Gender } & \\
& \text { Male } \\
& \text { Female } \\
& \text { Prefer not to say } \\
\end{array}$ & $\begin{array}{c}104 \\
94 \\
9 \\
\end{array}$ & $\begin{array}{c}50.5 \\
45.5 \\
4.3\end{array}$ \\
\hline $\begin{array}{c}\text { Consumer's Age } \\
\qquad 20 \text { years } \\
21-30 \text { years } \\
31-40 \text { years } \\
41-50 \text { years } \\
>51-\text { year s } \\
\end{array}$ & $\begin{array}{l}16 \\
78 \\
47 \\
39 \\
27 \\
\end{array}$ & $\begin{array}{c}7.7 \\
37.7 \\
22.7 \\
18.8 \\
13.0\end{array}$ \\
\hline $\begin{array}{c}\text { Consumer's Education Level } \\
\text { None } \\
\text { Basic/high } \\
\text { undergraduate } \\
\text { Postgraduate }\end{array}$ & $\begin{array}{l}55 \\
75 \\
46 \\
31\end{array}$ & $\begin{array}{l}26.6 \\
36.2 \\
22.2 \\
18.8\end{array}$ \\
\hline
\end{tabular}


End of Table 1

\begin{tabular}{|c|c|c|}
\hline Demography & Frequency & Percentage (\%) \\
\hline Consumer's Occupation & & 23.7 \\
Student & 49 & 24.6 \\
Formal sector & 51 & 32.9 \\
Informal sector & 68 & 18.8 \\
Other & 39 & 55.6 \\
Use of the green product & & 19.8 \\
Yes & 115 & 24.6 \\
No & 41 & 51 \\
\hline
\end{tabular}

\subsubsection{Chi-Square Tests}

For the purpose of this analysis, the chi-square test sought to evaluate the association and the dependence of demographic factors (gender, age, education, and occupation) on the use of the green product (dependent variable). Also, this technique further explores the association between any two given attributes regarding the cause-and-effect relationship. The test revealed that gender disparities have significant evidence in determining the use of the green product in the herbal industry. With the statistical analysis in Table 2, the asymptotic significance (2-sided) represents the $\mathrm{p}$-value of the measured variable. By virtue of this computation and interpretation, the $\mathrm{p}$-value of $0.024(\mathrm{p}<0.05)$ suggests that the chi-square test $(\mathrm{X} 2=11.211 \mathrm{a})$ is statistically significant in determining the relationship or association between gender (as the independent variable) and use of the green product (dependent variable).

Table 2. Chi-Square Tests (sources: Authors' computation from SPSS)

\begin{tabular}{|c|c|c|c|}
\hline & Value & df & Asymptotic Significance (2-sided) \\
\hline Pearson Chi-Square & $11.211^{\mathrm{a}}$ & 4 & .024 \\
\hline Likelihood Ratio & 11.304 & 4 & .023 \\
\hline Linear-by-Linear Association & 1.419 & 1 & .234 \\
\hline N of Valid Cases & 207 & & \\
\hline \multicolumn{2}{|l}{ 2 cells (22.2\%) have expected count less than 5. The minimum expected count is 1.78. } \\
\hline
\end{tabular}

Moreover, the technique deduced a symmetric measure (see Table 3) indicating nominal by nominal values (Phi and Cramer's V). The phi and Cramer's value describe the strength of relationship among the measured variables. With our computation of phi (0.233) and Cramer's (0.165) indicate the size of the effect, hence gender has a small-tomoderate effect on the use of the green product in a developing country perspective. However, since the 2-cells (22.2\%) is greater than 20 percent by chi-square rule, suggesting that our assumption is varied and therefore another action should be taken (see Table 4). To this end, the chi-square test in this context could not be justified or satisfied the statistical inferences from the data collected (Higgins \& Koch, 1977). We proceeded to run a correlation test for conformity of the chi-square test.

Table 3. Symmetric Measures (sources: Authors' computation from SPSS)

\begin{tabular}{|c|c|c|}
\hline & Value & Approximate Significance \\
\hline Nominal by Nominal Phi & .233 & .024 \\
Cramer's V & .165 & .024 \\
N of Valid Cases & 207 & \\
\hline
\end{tabular}

\subsubsection{Correlation test}

The aim of this subsequent test is to evaluate the extent of the relationship between the likeness of green product and the demographic factors of the consumers. Table 4 shows the statistical relationship (correlation coefficient) of the constructs (demographic factors) against the like and use of the green product. Meanwhile, readers should note that the 
strength of correlation coefficient ranges from -1 to +1 . For detail understanding, correlation coefficient with a negative sign indicates an indirect relationship between the predictive and the comparable variables whiles the positive values indicate a direct strength between the predictive and the control variables. The results from the Spearman's correlation coefficient $\left(\mathrm{r}_{\mathrm{s})}\right.$ table depicts the statistical strength on how the demographic factors influence and determine the likeness and use of the green (herbal) product.

Table 4. Correlation coefficient matrix (sources: Authors' computation from SPSS)

\begin{tabular}{|l|c|c|c|c|c|}
\hline & 1 & 2 & 3 & 4 & 5 \\
\hline 1. Gender & 1.00 & & & & \\
\hline 2. Age & $.208^{* *}$ & 1.00 & & & \\
\hline 3. Educational Status & .011 & $.626^{* *}$ & 1.00 & & \\
\hline 4. Occupation & .342 & -.264 & $.430^{* *}$ & 1.00 & \\
\hline 5. Use of Green(herbal) Product & -.108 & -.046 & .081 & -.206 & 1.00 \\
\hline
\end{tabular}

However, the results from the correlation coefficient matrix holds a contrary view from the hypotheses developed. This is because the correlated independent variables and their respective coefficients indicated an inverse relationship on the comparable variable (green product) for the exception of the educational level of the respondents. Even though educational level had a positive relationship (0.081) with the likeness of the green product but there was no statistical evidence to support this hypothesis since the significant value $(p>0.01)$. Again, to make inferences from the analysis, readers should note that, the general understanding of Table 4 is to observe the coefficient (strength of association) among the attributes. Our measurement shows that gender $(-0.108)$, consumer's age $(-0.046)$, consumers' educational status $(0.081)$, and consumers' occupation $(-0.206)$ have an inverse relationship to the use of the green product as indicated in Figure 3.

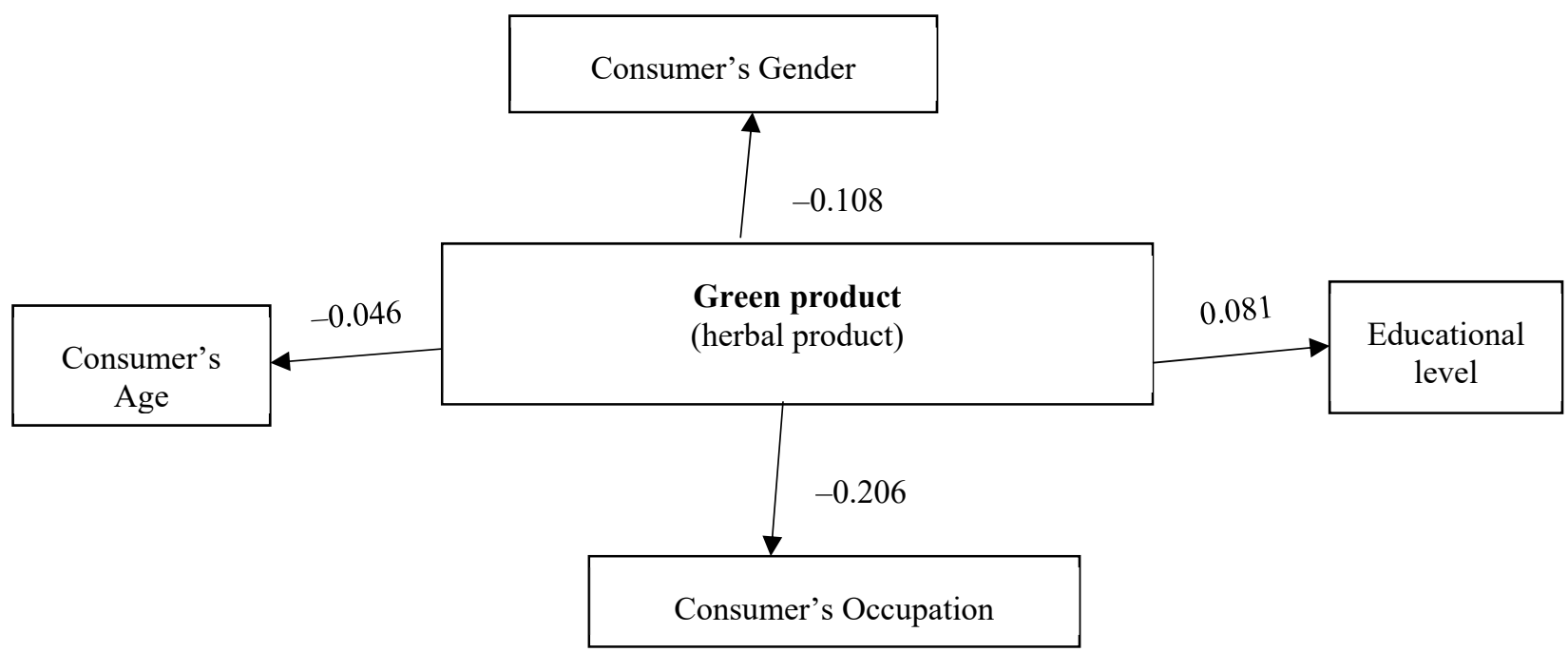

Figure 3. A conceptual framework with correlation coefficients (strength of association)

This computation suggests that demographic variables based on our population distribution do not determine the patronage and use of the green product in the context of Ghanaian green product market. By virtue of this analytical data and taken into consideration a significant error of $10 \%(0.01)$, It worth to know that the p-values of the measured constructs (demographics) were greater than 0.01 ( $\mathrm{sig}$. error). In this view, we say there is no statistical evidence to confirm the above mention hypotheses in the present study. Therefore, we fail to accept that.

H1: The use of the herbal product (green product) depends on gender.

This hypothesis does not hold to the present study and disputed with the evidence from previous study done by (Han et al., 2011; Valtonen et al., 2010), but collaborated with the work of (Straughan \& Roberts, 1999) that sex characteristic do not play any significant role in green consumer behaviour. We, therefore, fail to accept the null hypothesis 'The use of the herbal product (green product) depends on gender'.

H2: The use of the herbal product (green product) depends on the consumer's age. 
Also, this hypothesis could not hold to the present study. However, the alternate hypothesis rather supports the empirical works of Akehurst, Afonso, and Martins Gonçalves (2012). We, therefore, fail to accept the null hypothesis that 'The use of the herbal product (green product) depends on consumer's age'.

H3: The use of the herbal product (green product) depends on consumer's educational level.

Similarly, our empirical evidence does not hold the stated hypothesis, which further collaborated with the claims by Han et al. (2011) and Laroche et al. (2001) that education does not have a positive relationship with green consumer behaviour. We, therefore, fail to accept the hypothesis that 'the use of the herbal product (green product) depends on consumer's educational level'.

H4: The use of the herbal product (green product) depends on consumer's occupation.

Our result could not hold to this hypothesis, and also disputed the empirical evidence from Anderson Jr and Cunningham (1972), Roberts (1996) and Straughan and Roberts (1999) that socio-economic status of green consumers always perceived to have a positive influence with their attitudes and intentions. Henceforth, we fail to accept the hypothesis in this present study that 'the use of the herbal product (green product) depends on consumer's occupation'.

\section{Conclusion and recommendation}

The main objective of this paper was to measure consumers' inclination for the green (herbal) product in a developing country with respect to demographic variables. The partial goal is to evaluate the strength of association (effect) among the attributes (gender, consumers' age, consumers' educational status, and consumers' occupation). To evaluate consumer's view on the use of the green (herbal) product, 207 participants took part in the survey through structured selfreporting questionnaire and. Data were obtained from users of green products (specifically herbs) in Ghana.

Empirically, data shows a varied interpretation regarding the demographic outlook of the consumers. With a frequency table of demographic characteristics in Table 1 suggested that most (50.5\%) males are the dominant users of green (herb) product in the Ghanaian herbal market. The paper indicated the youthful population as the highest number of users of the green product in the herbal market. Findings from the nonparametric test (Spearman's rho) revealed that demographic factors (gender, age, education, and occupation) have an inverse relationship on the use of the green product. Though the correlation coefficient of education $\left(r_{\mathrm{s}}=0.081\right)$ in Spearman's correlation coefficient matrix depicted a positive association but the sig. value $(p>0.01)$ refuted evidence of association or dependence on consumers' education on the use of the green product. In summary, we conclude that there is no empirical evidence confirming the earlier hypotheses developed that demographic characteristics influence the use of the green product in this present study. Therefore, all the stated hypotheses could not be held.

The practical implication of this study gives insights to existing and up-and-coming herbal firms especially in the developing countries on how best they can progress in their quest to sustain in the business. Certainly, the theoretical benefit for this study would aid in widening the scope of consumer behaviour and brand management in the marketing discipline taken into consideration the widespread competition in the business nowadays especially in the herbal (green product) market. Even though consumers exhibit varied taste and preferences for a product, however, it is imperative for firms to understand the behaviour of consumers to enable them to strategize and respond to the demands of the market and stay competitive. Moreover, this current study further expands the horizon of the concept of consumer behaviour since the empirical analyses would add up to the existing related literature.

With regards to science, the paper contributes to the knowledge of consumer behavior in the green market. Our investigation gave a vivid understanding of consumers demographic impact tailored towards the herbal product in the green market. The results would, however, position scholars interested in this phenomena so far as consumer behaviour and marketing are concerned. With this knowledge, it would inform scholars and managers on full knowledge or information about green product differentiation and its association with consumers' demographic characteristics. The study provides some new evidence that herbal product as a category of green product, is a unique health product which does not dependent on demographics based on the current study.

The limitation of this study considered the research scope, taking into account a smaller sample size for the study. The research was also constrained with illiteracy level of some age group, mainly the aged, since many developing countries still have a significant number of persons unable to read and write especially, in the rural communities, hence making data collection very difficult. Also to ensure a geographical balance of data collection, the researcher was faced with financial constraint. Going forward, the author recommends that, future studies should be geared towards the country of origin perspective regarding the green (herbal) product. Lastly, cross-country-cultural analysis of this kind of study is recommended for future researchers. 


\section{Acknowledgements}

The project researchers are thankful and indebted to Dr. Bedrich Zimola (Vice-Dean for International Relation, TBU) for his regular consultancy offered to this project. We thank Assoc. professor Miloslava Chovancova (Project Guarantor) behind the successful completion of this article.

\section{Funding}

This work was supported by the Internal Grant Agency of FaME through TBU in Zlín No. IGA/FaME/2019/008; Project title: Country-of-origin effect on the domestic product (brand) purchasing intention and SME's sustainability in developing countries.

\section{Contribution}

Jibril, A. B (Principal Author) engineered the entire write up of the manuscript (including conception and design of the work, data analysis and interpretation). Kwarteng, M. A (co-author 2) designed the research hypothesis, question, and data collection while Miloslava, C. (co-author 3) did proofreading and critical revision of the article to suit intellectual content.

\section{Disclosure statement}

We agree that this manuscript once accepted could be published without any hindrance.

\section{References}

Agbonifoh, B. A., \& Elimimian, J. U. (1999). Attitudes of developing counties towards "country-of-origin" products in an era of multiple brands. Journal of International Consumer Marketing, 11(4), 97-116. https://doi.org/10.1300/J046v11n04_06

Aneesh, T., Hisham, M., Sekhar, M., Madhu, M., \& Deepa, T. (2009). International market scenario of traditional Indian herbal drugs-India declining... International Journal of Green Pharmacy, 3(3), 184-190.

Adjei, B. (2013). Utilization of traditional herbal medicine and its role in health care delivery in Ghana: The Case of Wassa Amenfi West District. Retrieved from http://hdl.handle.net/123456789/5332

Akehurst, G., Afonso, C., \& Martins Gonçalves, H. (2012). Re-examining green purchase behaviour and the green consumer profile: new evidences. Management Decision, 50(5), 972-988. https://doi.org/10.1108/00251741211227726

Anderson, Jr. W. T., \& Cunningham, W. H. (1972). The socially conscious consumer. Journal of Marketing, 36(3), 23-31. https://doi.org/10.1177/002224297203600305

Awad, T. A. (2011). Environmental segmentation alternatives: buyers' profiles and implications. Journal of Islamic Marketing, 2(1), 55-73. https://doi.org/10.1108/17590831111115240

Balabanis, G., Diamantopoulos, A., Mueller, R. D., \& Melewar, T. C. (2001). The impact of nationalism, patriotism and internationalism on consumer ethnocentric tendencies. Journal of International Business Studies, 32(1), 157-175. https://doi.org/10.1057/palgrave.jibs.8490943

Bempong, G. B. (2017). The effect of green branding on consumer purchasing behavior: A study of the Ghanaian cosmetic market. Retrieved from https://air.ashesi.edu.gh/handle/20.500.11988/324

Berkowitz, L., \& Lutterman, K. G. (1968). The traditional socially responsible personality. Public Opinion Quarterly, 32(2), 169185. https://doi.org/10.1086/267597

Brown, S. (1999). Retro-marketing: yesterday's tomorrows, today! Marketing Intelligence \& Planning, 17(7), $363-376$. https://doi.org/10.1108/02634509910301098

D'Souza, C., Taghian, M., Lamb, P., \& Peretiatko, R. (2007). Green decisions: demographics and consumer understanding of environmental labels. International Journal of Consumer Studies, 31(4), 371-376. https://doi.org/10.1111/j.14706431.2006.00567.x

Elvin-Lewis, M. (2001). Should we be concerned about herbal remedies. Journal of Ethnopharmacology, 75(2-3), 141-164. https://doi.org/10.1016/S0378-8741(00)00394-9

Han, H., Hsu, L.-T. J., Lee, J.-S., \& Sheu, C. (2011). Are lodging customers ready to go green? An examination of attitudes, demographics, and eco-friendly intentions. International Journal of Hospitality Management, 30(2), 345-355. https://doi.org/10.1016/j.ijhm.2010.07.008

Herbal medicine market size and forecast, by product (tablets \& capsules, powders, extracts), by indication (digestive disorders, respiratory disorders, blood disorders), and trend analysis, 2014-2024. (2017). Hexa Research. Retrieved from https://www.hexaresearch.com/research-report/global-herbal-medicine-market

Higgins, J. E., \& Koch, G. G. (1977). Variable selection and generalized chi-square analysis of categorical data applied to a large cross-sectional occupational health survey. International Statistical Review/Revue Internationale de Statistique, 45(1), 51-38. https://doi.org/10.2307/1403003 
Jibril, A. B. (2017). Projekt na posileni prodeje značkových rostlinných produkti̊ Konate Herbal Center v Ghana. Zlín: Univerzita Tomáše Bati ve Zlíně, 2017, 116 s. Retrieved from http://hdl.handle.net/10563/42251 (in Czech).

Kairu-Wanyoike, S. W., Kiara, H., Heffernan, C., Kaitibie, S., Gitau, G. K., McKeever, D., \& Taylor, N. M. (2014). Control of contagious bovine pleuropneumonia: Knowledge, attitudes, perceptions and practices in Narok district of Kenya. Preventive Veterinary Mezdicine, 115(3-4), 143-156. https://doi.org/10.1016/j.prevetmed.2014.03.029

Kim, Y. (2011). Understanding green purchase: The influence of collectivism, personal values and environmental attitudes, and the moderating effect of perceived consumer effectiveness.

Kotler, P., \& Gertner, D. (2002). Country as brand, product, and beyond: A place marketing and brand management perspective. Journal of Brand Management, 9(4), 249-261. https://doi.org/10.1057/palgrave.bm.2540076

Kumar, M. R., \& Janagam, D. (2011). Export and import pattern of medicinal plants in India. Indian Journal of Science and Technology, 4(3), 245-248.

Laroche, M., Bergeron, J., \& Barbaro-Forleo, G. (2001). Targeting consumers who are willing to pay more for environmentally friendly products. Journal of Consumer Marketing, 18(6), 503-520. https://doi.org/10.1108/EUM0000000006155

Lu Wang, C., \& Xiong Chen, Z. (2004). Consumer ethnocentrism and willingness to buy domestic products in a developing country setting: testing moderating effects. Journal of Consumer Marketing, 21(6), 391-400. https://doi.org/10.1108/07363760410558663

Pal, S. K., \& Shukla, Y. (2003). Herbal medicine: current status and the future. Asian Pacific Journal of Cancer Prevention, 4(4), 281-288.

Madow, W. G. (1968). Elementary sampling theory. Technometrics, 10(3). https://doi.org/10.1080/00401706.1968.10490610

Makunga, N. P., Philander, L. E., \& Smith, M. (2008). Current perspectives on an emerging formal natural products sector in South Africa. Journal of Ethnopharmacology, 119(3), 365-375. https://doi.org/10.1016/j.jep.2008.07.020

Olken, F., \& Rotem, D. (1986). Simple random sampling from relational databases.

Pal, S. K., \& Shukla, Y. (2003). Herbal medicine: current status and the future. Asian Pacific Journal of Cancer Prevention, 4(4), 281-288.

Pan, S.-Y., Litscher, G., Gao, S.-H., Zhou, S.-F., Yu, Z.-L., Chen, H.-Q., Zhang, S.-F., Tang, M.-K., Sun, J.-N., \& Ko, K.-M. (2014). Historical perspective of traditional indigenous medical practices: the current renaissance and conservation of herbal resources. Evidence-Based Complementary and Alternative Medicine, 2014, 1-20. ID 525340. https://doi.org/10.1155/2014/525340

Pandey, P., Singh, S., \& Dalla, S. A. (2017). Conceptual framework of relationship between promotional tools \& consumer buying behavior. International Education and Research Journal, 3(5).

Patwardhan, B., Vaidya, A. D. B., \& Chorghade, M. (2004). Ayurveda and natural products drug discovery. Current Science, 789799.

Raskin, I., Ribnicky, D. M., Komarnytsky, S., Ilic, N., Poulev, A., Borisjuk, N., Brinker, A., Moreno, D. A., Ripoll, Ch., Yakoby, N., O'Neal, J. M., Cornwell, T., Pastor, I., \& Fridlender, B. (2002). Plants and human health in the twenty-first century. Trends in Biotechnology, 20(12), 522-531. https://doi.org/10.1016/S0167-7799(02)02080-2

Rath, B. (2005). Globalization, global trend in herbal market, and the impact thereof on medicinal plants in Orissa. Vasundhara. Bhubaneswar.

Roberts, J. A. (1996). Green consumers in the 1990s: profile and implications for advertising. Journal of Business Research, 36(3), 217-231. https://doi.org/10.1016/0148-2963(95)00150-6

Samiee, S., Shimp, T. A., \& Sharma, S. (2005). Brand origin recognition accuracy: its antecedents and consumers' cognitive limitations. Journal of International Business Studies, 36(4), 379-397. https://doi.org/10.1057/palgrave.jibs.8400145

Semenya, S., Potgieter, M., Tshisikhawe, M., Shava, S., \& Maroyi, A. (2012). Medicinal utilization of exotic plants by Bapedi traditional healers to treat human ailments in Limpopo province, South Africa. Journal of Ethnopharmacology, 144(3), 646655. https://doi.org/10.1016/j.jep.2012.10.005

Sharma, A., Shanker, C., Tyagi, L. K., Singh, M., \& Rao, C. V. (2008). Herbal medicine for market potential in India: an overview. Academic Journal of Plant Sciences, 1(2), 26-36.

Straughan, R. D., \& Roberts, J. A. (1999). Environmental segmentation alternatives: a look at green consumer behavior in the new millennium. Journal of Consumer Marketing, 16(6), 558-575. https://doi.org/10.1108/07363769910297506

Thongruang, C. (2008). Consumer purchasing behavior for herbal medicine in drugstore in Bangkok. Naresuan University Journal: Science and Technology (NUJST), 16(3), 195-202.

Valtonen, A., Markuksela, V., \& Moisander, J. (2010). Doing sensory ethnography in consumer research. International Journal of Consumer Studies, 34(4), 375-380. https://doi.org/10.1111/j.1470-6431.2010.00876.x

Van Andel, T., Myren, B., \& Van Onselen, S. (2012). Ghana's herbal market. Journal of Ethnopharmacology, 140(2), 368-378. https://doi.org/10.1016/j.jep.2012.01.028

Watson, J. J., \& Wright, K. (2000). Consumer ethnocentrism and attitudes toward domestic and foreign products. European Journal of Marketing, 34(9/10), 1149-1166. https://doi.org/10.1108/03090560010342520

Warner, S. L. (1965). Randomized response: A survey technique for eliminating evasive answer bias. Journal of the American Statistical Association, 60(309), 63-69. https://doi.org/10.1080/01621459.1965.10480775 